\title{
東京市西部井荻, 天沼地下水堆1
}

\author{
吉 村 信 吉
}

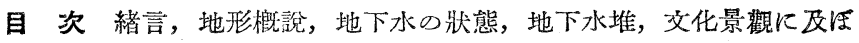
す地下水堆の影響, 摘要, 參考文獻

緒 言 武藏野臺地の東，東京市新市域の外縁に當り北多摩郡田無町，保 谷村に又六, 上宿の兩地下水堆，三鷹村に仙川地下水堆があり，古い聚落發 生と關係することは別文に發表した通りである（吉村1939，1940）。其後兩者 の中間，杉並區の西に一層大きいるのを發見したから報告し，併せてこれら の地下水堆と比較考察しるうと思ふ。本交の終にも迅へミる通り武藏臺地東部 に他に相當の擴りを有つ地下水堆の存在する餘地はないやうであるから, 地 下水堆に關する論文はこれを以つて一先づ終ることにする。野外調查に助力 された古川啓爾氏及研究費を補助された日本學術振興會に感謝の意を表する。

\section{地 形 概 說（第1 圖）}

本文に取扱ふ地域は井,頭池から出る神田川の支流善福寺川と妙正寺川の 上流とに摤まれる臺地であつて，行政上東京市杉並區三谷町，今川町，中通町， 淸水町，井荻 2 丁目，宿町，關根町，上荻梁 2 丁目，天沼 $1 ， 2 ， 3$ 丁目， 阿佐谷 2，3，4，6 丁目，荻窪 2，4 丁目，西田町 1 丁目，成宗 1 丁目等の 諸町に跨つてねる。本地域の地形は 2 萬分 1 中野圖幅 (明治42年测圖)， 2 萬 5 千分 1 , 東京西郊圖 (大正 6 年測圖, 昭和 12 年修正) 及び 1 萬分 1 荻䆶, 上高井 戶(共に昭和 4 年測圖)及び吉样寺 (昭和 12 年測圖)によつて知ることが出來る。

著者は土に終の 3 圖幅所載の高度によつて地下水の面の高度を算出した。第

（1）武藏野臺地の地下水第７報 


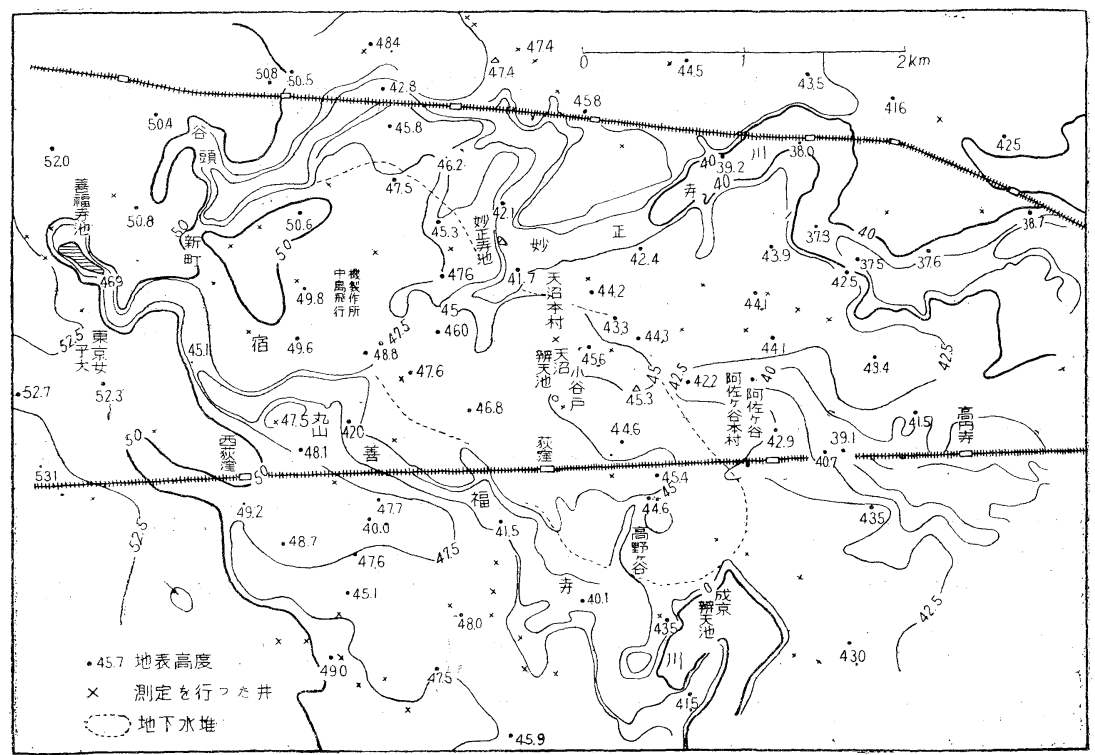

第 1 圖 井荻, 天沼地下水堆 (點線内の地域) 附近の地形

（數字は 1 萬分 1 地形圖による磦高）

1 圖は 1 萬分 1 地形圖を縮圖したものである。

本地域の高度は西の $52 \mathrm{~m}$ から東の $44 \mathrm{~m}$ までである。全體は極めて数に 傾斜する武藏野臺地面をなしてるるが，單調を破り淺い谷が二，三ある。北 の8の纺妙正寺川で善福寺池東北の舊小字谷頭（現在柇並區新町）に源を發し， 大をく蛇行しつ〉東に流礼舊大字下井草 (現沓掛町)にある妙正寺池の水を合 して東に向ひ，落合で神田川に合する。谷底の幅は $100 \mathrm{~m}$ を少し超え深さ 3〜 $5 \mathrm{~m}$ ，所々水田化されてるる。妙正寺池は Stiny（1936）の所謂沼澤狀柕 泉 Sumpfquellen である。ローム愿下部の粘土上に帶水する地下水が流出 するのであつて一面にヨシが繁茂し，中島には辨天が祀られてるる。

䡬福寺川は美事度杓子狀滗池（Stiny の圆形谷壁汿泉, Nischquellen, Rundnitchen, Kesselnischen) 中に湛えられる善福寺池に發する。善福寺池附近の 


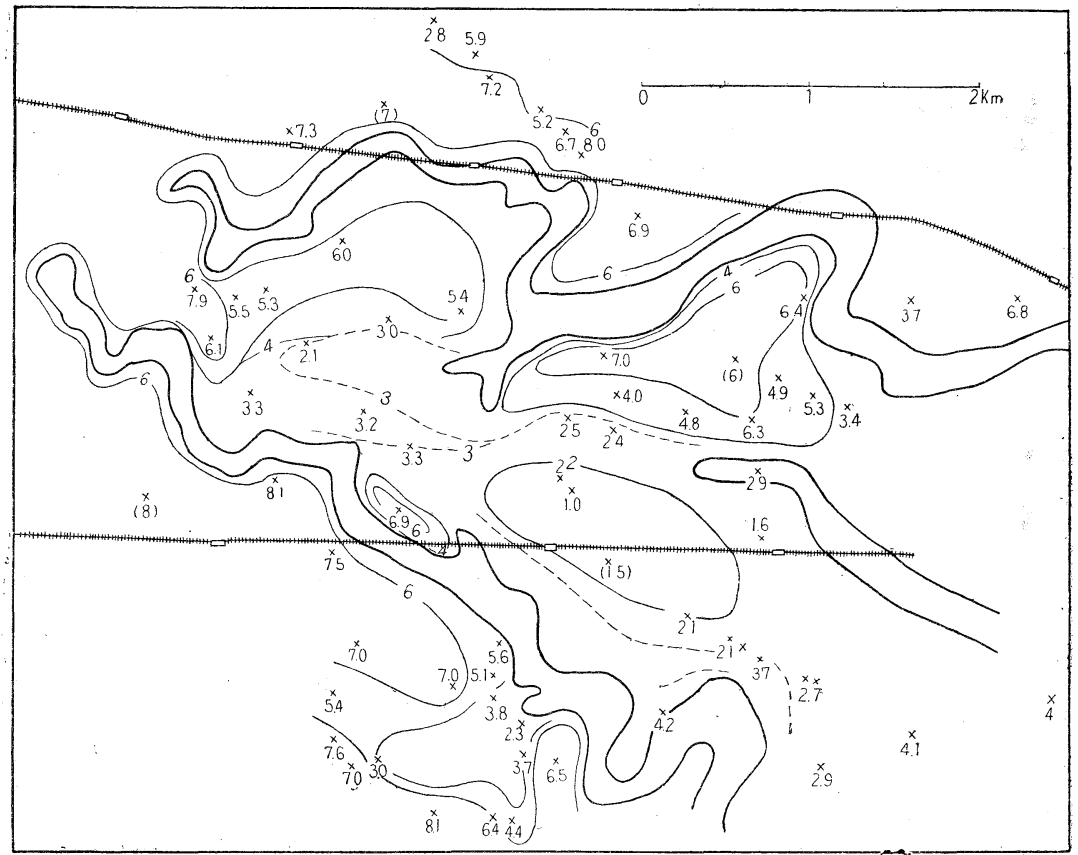

第 2 圖地下水面の深さ $(\mathrm{m})$, 太線壮谷壁老示す

地下水には 2 種ある。1 は池面より上，侵蝕崖に露出するローム層下部の粘 土層から滲出し池中に瀉下するものである。他は粘土層下部の砂礫層中に帶 水し, 池底から涌出するもので，湧水個所は大八釜と呼ばれてねる。大正 4 年 7 月には全體の流出量 9 個 (吹 ${ }^{3}$ 秒) であつた（中野, 小倉 1920)。池の西北 の中島には辨天社がある。元は池面に水草繁茂してるたが，今は廣く掘り起 され貸ボートが營業されてるる。流出する川は蛇行しつ〉東南に流れ淀橋で 神田川に合する。その中流成宗には成宗辩天池があり，妙正寺池と共に後に 迅べる地下水堆の水が涌出するものである。元は川水の一部を辫天池の水と 共に暗渠で東方，馬橋にある谷に導き水田の灌溉に供しておた。

地域の東部に阿佐ヶ谷川(假稱)の淺い谷がある。前記兩川とは異なり臺地 


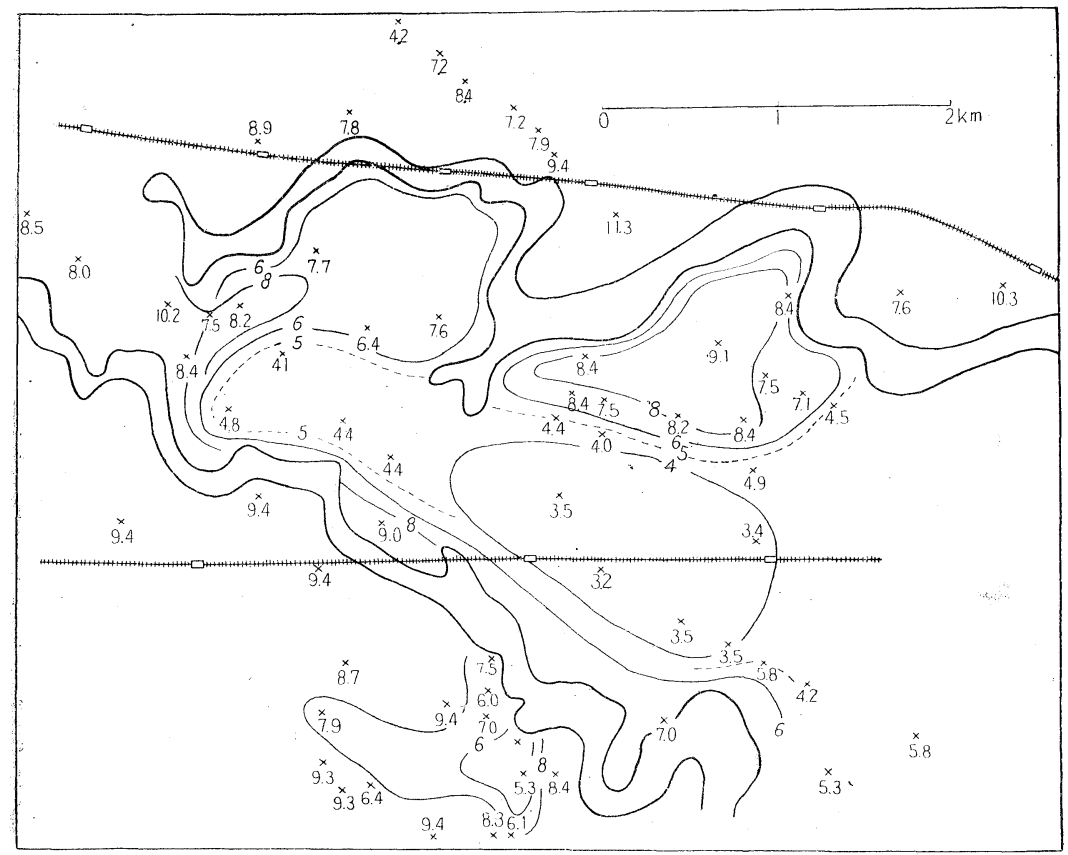

第 3 圖井底心深さ (m)

上飞湛えられる天沼の辨天池に源を發し，以前は狹い水田の間を阿佐っ谷に 至り(第10圖)，中野區棠園通の谷となり柏木で神田川に合する。この谷の上 流は元は玉川上水の一部，下流は上記成宗辨天池の水を分水して灌溉してな た。天沼の辩天池はョシやセキショウモの繁茂する小池で中島にはやはり辩 天が叔られてるる。井,頭池などとは異なり臺地の原面に溜つてねることは 注意すべきである。

\section{地下水の狀態}

著者が最初に本地域の地下水を調查したのは昭和 13 年 6 月 19 日であつた。 當時本地域の西の井（宿町 193，田中重喜氏所有）の地下水面の深さ $1.6 \mathrm{~m}$ ， そ の西方 $550 \mathrm{~m}$ 飞ある井（新町 65, 本多清藏氏所有）は $6.7 \mathrm{~m}$ (以西は $6 \sim 7 \mathrm{~m}$ ) で, 


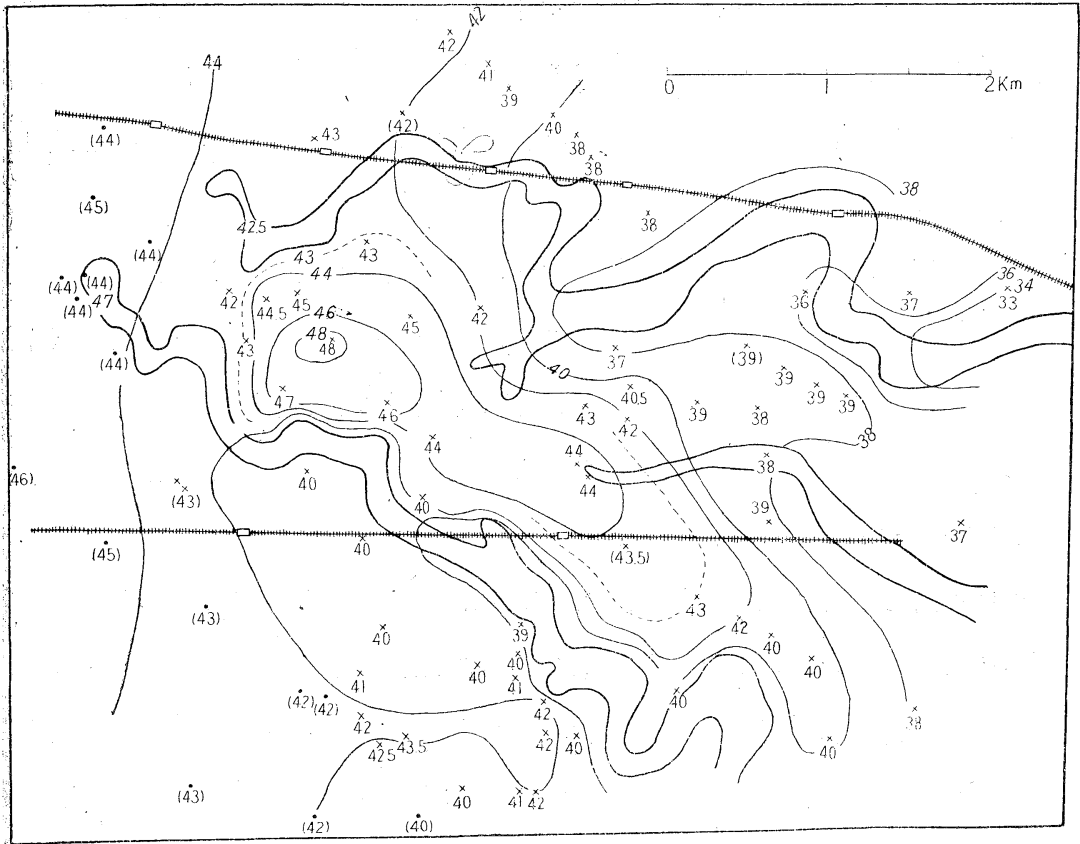

第 4 圖地下水面 0 高さ (m)

$5 \mathrm{~m}$ の差が認められた。同年12月 3 日の一齊調查の時には青梅街道に沿つ て調查し，宿町，三谷町の附近で東側の开の地下水面の深さ $2.7 \mathrm{~m}$ に對し西 方では $7.3 \mathrm{~m}$ で，約 $4.6 \mathrm{~m}$ の差があつた。嫦時地下水准に對する著者の智識 がそしく，精查するに至らなかつた。楚14年秋保谷村の上宿地下水堆を研究 した結果，本地域にも地下水堆が存在するのでは质いかと思ひ，15年 1 月 19， 23日の兩日本地域と他の疑問個所大宮前の61井について測定を用ひ，爿態を 明かにすることが出來た。

第 2, 3,4 圖に昭和 15 年 1 月 19 日及 23 日に於ける地下水面及び井底の 深さ，並に地下水面の高度分价を揭げる。

地下水面の深さ（第 2 圖） 當特冬の低水季に加ふるに 14 年 12 月以來雨 
量が少なかつたので地下水面は法ぶ平年の最低水位に當り，地下水面の深さ も本年としては最大に近かつたものも思はれる。圖中（）内の數字は昭 和 13 年 11 月下旬に测定しをものに附近の井の 2 回の測定值の差から推算し を補正值を加へ它のである。

妙正寺川以北及善福寺川以南の臺地面は大宮前 (善福寺の南) 附近のやうに 淺い雍地を除けば 6〜8m の間にあり, 兩川間の臺地の地下水面の深さる宿 町以西怯 $7 \mathrm{~m}$ 內外である。この數字は吉祥寺附近の相當廣い地域に互つて一 定してねる。宿町以東兩川間の臺地でる妙正寺川が北に蛇行する部分(中野區 䉆宮二丁目)は $6 \mathrm{~m}$ 内外飞達する。

これに對し宿町以東の臺地の中央（名心゙青梅街道附近）の地下水面は淺く， 宿町は $3.3 \mathrm{~m}$ で地形が甚だ本坦であるにも關はらず西北部臺地のものよりも $4.6 \mathrm{~m}$ る淺く, その間深さが急變してねる(第 8 圖)。その急變は後述のや了 に臺地の他の部分ににある宙水域外緣部に於けるものよりは勿論，地下水瀑 布線附近のものに比しても緩い。南南西に向ひ天沼, 成宗に至る迄づつと谜 だ淺く，殊に天沼辨天池附近の井は臺地原面より $1 \mathrm{~m}$ 位降つた寉地にはある が，水面迄僅か $1.0 \mathrm{~m}$ に過ざないのがある(第 8 圖)。辨天池に於ては地下 水面が臺地面に出てるる。東方に向つて恰、に深くなり，明膫な境界線は 存在しないが, 北方阿佐っ谷 6 丁目に向つては相當急に深く, 妙正寺川の谷 壁に近い所では 6.5〜7m と達する。

井底の深さ（第3 圖） 本地域井內湛水の深さは當時法ぶ一定してねたので 井底の深さの分布は地下水面の深さの分布(第 2 圖) とょく似てねる。上記淺 水帶の井戶の深さは 3.5 4.5m で冲積平野の井に匹適する程淺く竹等の先に バケツを括つて波み上げてねをりのもあつた。淺水帶の周圍の井は $8 \sim 10 \mathrm{~m}$ 內外，淺水帶との境は急變してわた。 
地下水面の高さ（第4 圆）本地域より8西方臺地の地下水面は緩に東に向 ひ傾斜し，善副寺池の東では $42 \sim 43 \mathrm{~m}$ となる。本地域附近でも妙正寺川の 北や善福寺川の南の臺地は西方登地のや马に徐々に東に向ひ傾斜し本地域の 東では $38 \mathrm{~m}$ 內外になる。

これに對し本地域の東三谷町に入ると，地形とは反對に東に向ひ地下水面 は上昇し，缩町の中島飛行機製作所の西に於ては $48 \mathrm{~m}$ に達し，西方よりも 5〜6m 高い。南に向つては善福寺川の谷又はその少し北に於て $4 \mathrm{~m}$ 8高京 つてねる。北に向つては中島飛行機製作會社の北で徐々に低下してるる。東 方天沼町方面は臺地中央で合 $44 \mathrm{~m}$ に達し，天沼町の北では臺地內に於て急 に 4 5m \&低く, 暫くの間そのま〉に妙正寺川の谷に至る。東に向つては 急に低下する個所はない。

かやうに三谷町から天沼町にかけ地形とは無閵係に四周から孤立して地下 水面が高まつてるのが認められる。後に述べるやうに地質及び地下水面の狀 態から見て西北部武藏野臺地にある宙水域（吉村1940）とは全く狀態を異にし， 主地下水面が塚狀に盛上つてねるのである。著者はこれを井荻, 天沼地下水 堆 Iogi-Amanuma Ground-water Mound と呼ぶこととする。詳細は次章 に述ベる。

善福寺川の南の神田川との間の臺地にある大棠前春日神社附近の篗地に沿 ひ，地下水面は兩側より僅か高く小規模索がら地下水堆をなしてねるやうに 見える。しかし高まりは1〜2mであつて著者の採つてるる测定の程度では 真の高まりか誤差によるのかの境にあり，精密な測定が行はれない中は地下 水堆とは認めないことにする。

(1) 井荻は井草，荻䇠を合併した時えれらの頭字をとつたものである。元は大きな町 であつたが，東京市に合併された時數多の小さい町に分割され，その名は西の一 劃だけに殘つてるる。 
地下水の水素イオン濃度 $\mathrm{pH}$ 昭和 15 年 1 月に行つを $\mathrm{pH}$ の測定(現場 で B. C. P.を用ひ定量) 結果恃第 5 圖のやうである。昭和 13 年 11 月下旬に於 ける测定值もこれと殆ど同樣であつたから改めて迅べない地下水堆の輪颜 と完全には一致しないが東西に比較的酸物の

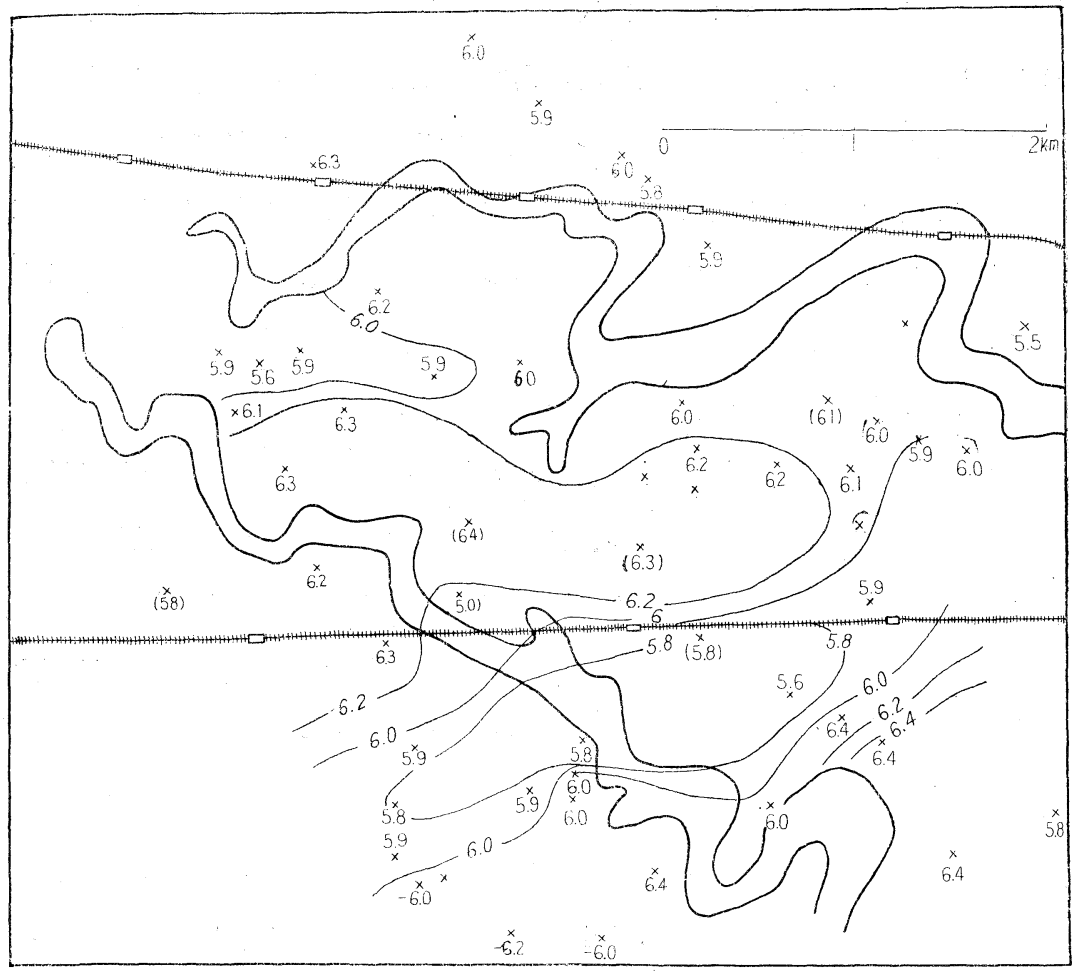

第 5 圖 地下水の $\mathrm{pH} （ ）$ 內の值は 1938 年 11 月測定

四周の微酸性 $(\mathrm{pH}=6.0)$ の地下水と區別される。殊に西に向つては地下水堆 の境界に於て pH は 6.3 から 5.9 亿變化する。一方中央線の少し南を地下 水堆とは無關係に微酸性（pH=5.8）の帶が東西に貫いてるる。 $\mathrm{pH}$ 分布は测 定の誤差や偶然でなく何物かを意味するやうであるが，立入つて研究してね 
ないので本文には事實の記載のみに止めることとする。

\section{地下 水 堆}

井荻, 天沼地下水堆の平面形は西北西一一東南東の長軸を有つ楕圓をなし, 長徑 $3.5 \mathrm{~km}$ ，短徑 $1.1 \mathrm{~km}$ ，面積約 $3 \mathrm{~km}^{2}$ である。四周の一般地下水面より

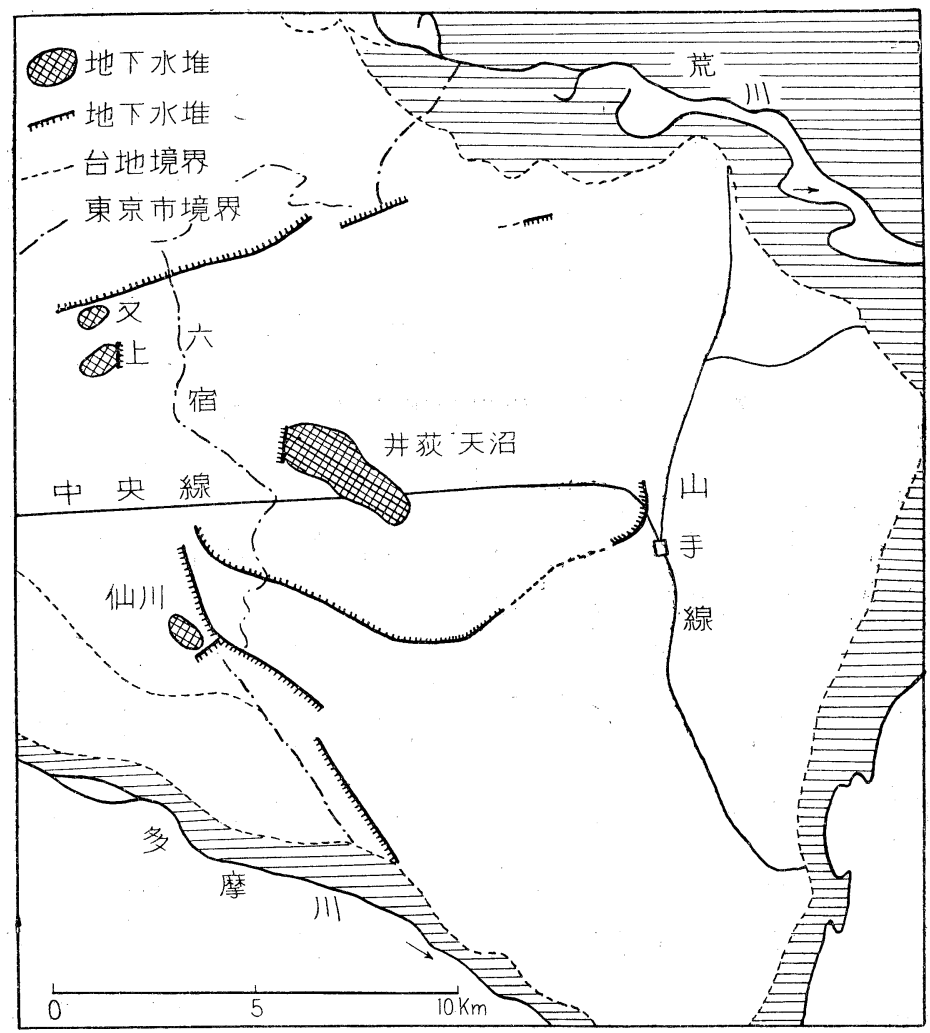

第 6 圖 身部武藏野裳地の地下水堆と地下水瀑布線

の高まりは 5〜6m である。これを著者（吉村 1939, 40）が既に報告した他の 地下水堆と比較すると第 1 表のやうである (第 6, 7 圖)。

本地下水堆は他の\&のに比し大形であるが，高さはほぶ等しいから地下水 


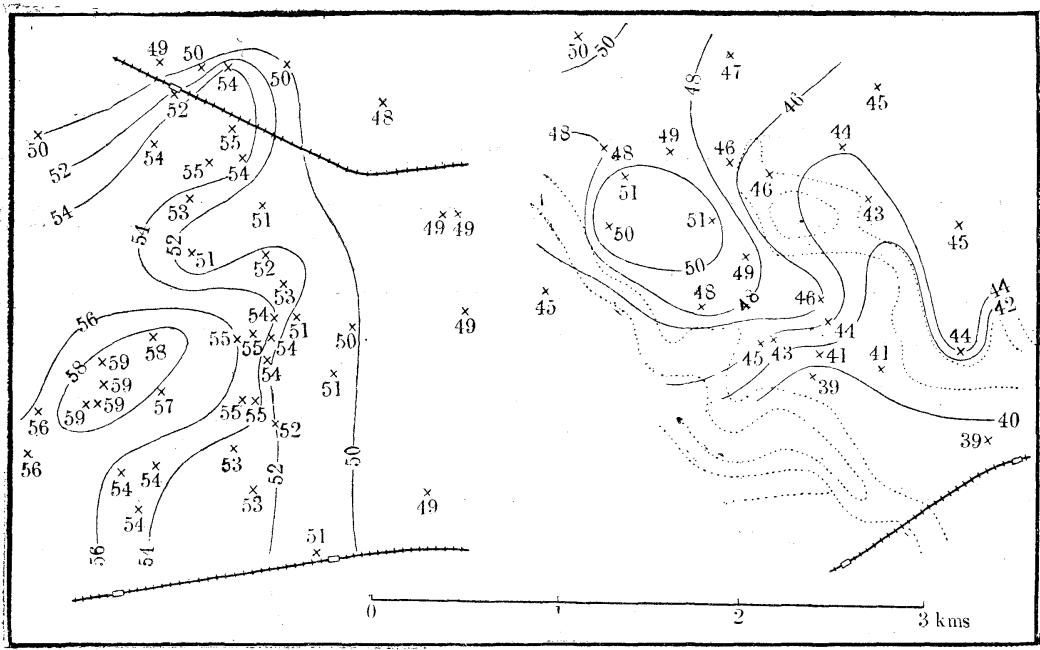

第 7 圖 上宿及们川地下水堆（吉村1940）

\begin{tabular}{|c|c|c|c|c|c|c|c|c|c|}
\hline 名 & 稱 & 所 & 在 & 地 & 長 & $\mathrm{km}$ 烼 & 短 $\mathrm{km}$ & 徑 & 高 $\mathrm{m}$ \\
\hline 赑 & 六 & 保 & 谷 & 村 & & 1.0 & 0.7 & & $4 \sim 5$ \\
\hline 上 & 宿 & & 村, & 照町 & & 1.4 & 0.8 & & 5 \\
\hline 井 荻, 天 & 沼 & 杉 & 並 & 區 & & 3.5 & 1.1 & & $5 \sim 6$ \\
\hline 仙 & 川 & $\equiv$ & 䳡 & 村 & & 1.3 & 0.8 & & 5 \\
\hline
\end{tabular}

面の平均傾斜は小さい。輪階は四者共全部楕圓形である。

以上の 4 地下水堆の地下水面の動水傾辇の分布を通觀すると，資料が完全 でないから斷定することは出來ないが，頂部から長軸及び短軸方向へはドー ム狀をなしてるる。更に細く見るとある部分は緩いが，所によつては長軸の 方向にさへ相當に急で一種の地下水瀑布をなしてるる。井荻, 天沼地下水堆 以外の地下水堆は長軸に沿ひ一般地下水面の高くなる方向に傾科が小さいが， 井荻, 天沼地下水堆の長軸に沿ひ一般地下水面の高くなる方向郎ち西に急で ある。又六及び上宿地下水堆は一方側だけが急斜し，仙川地下水堆は三方が 
急科し，井荻，天沼地下水堆は二方（西及西南，霉北）が急科してるる。 從つて斷面の地形は短軸に\&對して\&長軸にしても非對稱的である（第 8,9 圖)。

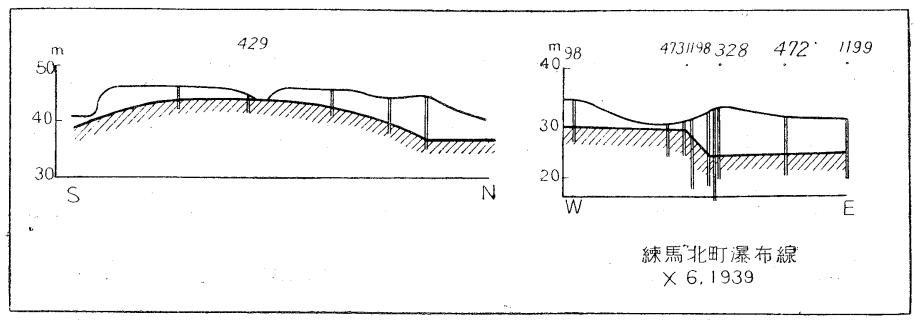

第 8 圖 井荻,天沼地下水堆の南北斷面 (左) と地下水暴布線 （右）との地下水面の動水傾斜の比較

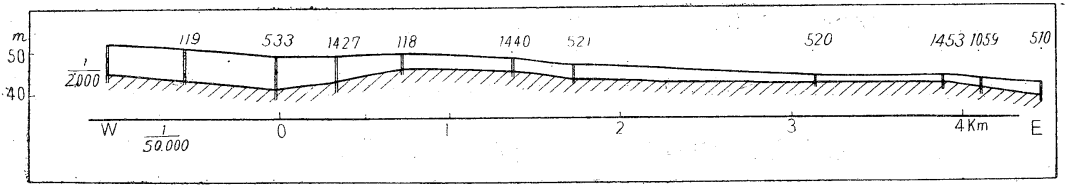

第 9 圖 井荻,天沼地下水堆の東西潪面

地下水面が复科してわると云つても別交に報告した地下水瀑布線に比較し 次のやうな點で異なつてるる。

（1）動水傾斜は $\frac{1}{150}$ 以下で, 瀑布線附近が-1 るのに比し著しく小さい。

（2）地下水瀑布線は直線又はそれに近いが，地下水堆の急斜線は弧の一部 をなし，且短い。

宙水域とは地下水等高線圖からのみ比較すると一見似てねるやうであるが， 宙水域は本水との間に急に數米，又は十數米の落差があり，且途中の高さの 地下水位を有つ井がないことから畐別出來る（吉村 1940）。

井荻，天沼方面にある侵蝕谷は淺く露頭にはローム㴊が出てねるだけの所 
が多く，地下水堆上の井もローム懕だけに掘られてるるので地質が分らない。 西方善福寺池附近の崖には前記のやうにローム層下部に粘土層化した所があ つてそこに涌水がある。こつの粘土の厚さは 1〜2m 程度で池底には砂礫曆 が出てねると云ふ。

しかし本地域には工場, 學校, 水道水源地がある爲試錐多く，地質を知る資 料となる。善福寺池畔にある舊井荻町水道の鳘井は谷底から數米が泥でその 下に $10 \mathrm{~m}$ 前後の粗砂と砂磷との互層があり，その下に $10 \mathrm{~m}$ 近くの粘土層が ある。臺地面から云ふと，これに谷の深さ $6 \mathrm{~m}$ を加一地表下 10〜20m に砂

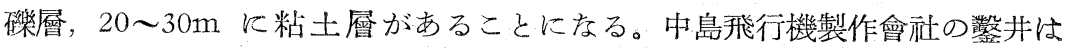
地表から 4.5m までローム，4.5〜10m は粘土，10〜16m は砂礫，16〜17m は赤色粘土，17〜22 $\mathrm{m}$ は砂䃯，22～25 $\mathrm{m}$ は粘土であつた。地域の東，高圓 寺管並業試驗場の井は 0〜8m ローム，8～11m 青色粘土交り砂，11～18m 砂磁 曆，18m に土盤があり，18～25m 砂䃯である。西尾工學士 (1938) は荻涩驛 前電話局敷地の 2 井に於てローム層の下に夫љ $4.5 \mathrm{~m}, 3.5 \mathrm{~m}$ の厚さの毒灰色 又は灰色の砂質粘土層の存するこそを西尾式試錐によつて知り，その物理的 性質は下部にある東京層の粘土層と異をり軟弱で，冲積層の粘土と同じであ ることを指摘してるる。何れにしても砂礫曆は $10 \mathrm{~m}$ 以深にあるので弦に述 ベるやうな地下水には無關係であつて，地下水はローム黁下部に，その下に ある粘土壓を不透水㬝として帶水してるる。

この粘土厭は鈴木博士 (1888)，清野理學士（1935）以來注意されてねるや ろに，所によつては㕌いが所によつては溥く，時には砂層に置換へられてる る。本地域の西，吉神寺では露頭觀察並に試錐によると存在せず，善稫寺池 附近では $2,3 \mathrm{~m}$ の厚さで夾在し，井荻町では $5 \mathrm{~m}$ に達し，東方高圓寺では再 び薄くなる。これからも分るやうに地下水錐のある所は粘土檿が極めて厚い 


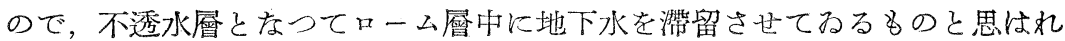
る。或は粘土檿表面が洼み帶水に都合がよくなつてみるのかも知れないが， 資料がないから斷定することは出來ない。

この地質に加ふるにその西に於ては妙正寺川，善福寺川の上流が相接し， 地下水は涌水となつて地上に出るので，西部の地下水面の方が反つて東部よ り多低くなるのであらう。

\section{交化景觀に及ぼす影響}

續日本紀に神護景雲 2 年 (768 年) 東海道按擦使，式部大輔紀廣名等言，武 藏國乘潴，豊島二驛，承山海兩路，使命繁多，公準中路，置馬十匹，奉勅依 奏とある。乘潴は「ノリヌマ」と訓むべきであるが古書に乘, 剩相通用し「アマ ヌマ」とも訓めるので，こ〉のことではないかと故吉田東伍博士(大日本地名 䉸書, 明治40年, 再版 p. 2844) は說いて子る。もしもこの通りであれば天沼の 發生は古いので甚だ面白いが，天沼の地名は武藏野臺地東部にはこ〉の外に も三，三あるから，他に有力の資料がなければこ〉の天沼に該當するかを斷 定し得られないやうに思子。

新編武藏風土記稿によるとこの方面にあつた德川時代の村々，上井草，下 井草，上荻㕠，下荻靯，天沼，成宗，田端，阿佐ヶ谷等總べて德川時代以前 に生れた古村で正保年間の圖中に記されてねる。小田原家人所領役帳に「島 津孫四郎知行甘一貫文，永福寺沼袋成宗」又「太田新六郎知行八十四貫交中 野內阿佐ヶ谷，同人知行十六貫二百九十文千束內阿佐ヶ谷分」とある。上荻 淮村は天正 19 年 9 月 24 日柏木右近，小林大辨，服部清助，加藤二三郎，淺 沼但馬等，成宗は慶長16年岡部小太衞門が檢地し，德川時代初期に存在して ஓたことを如實に示してねる。

小田內通敏氏は阿佐ヶ谷, 天沼, 荻洼等の村々（東京市合併前の大字に當る）の 


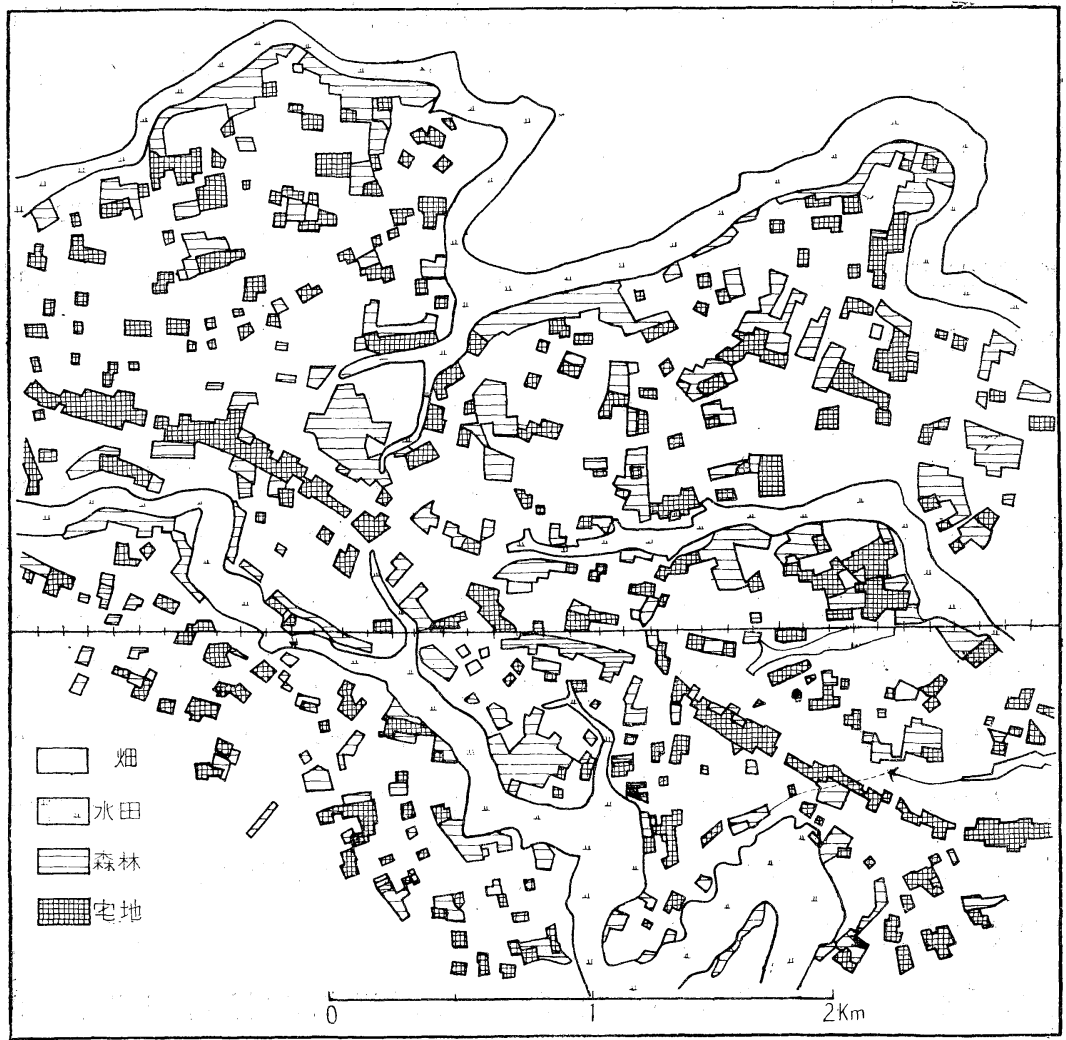

第 10 圖 井荻‥”沼方面の景觀 （明治42年）（2萬分1中野蜸幅）

本村が谷に沿ふ臺地にあることを指摘してねる。これらは何れも地下水堆の 上に載つてるるので，本地下水堆は古村の發生に關係があるやうである。し かし井荻, 天沼地下水堆四周の村は先に述べた上宿，谷戶や仙川本村の四周 の部落とは異なり，古い村で德川時代に出來た新田村としては南の大宮前新 田あるのみであるから，地下水堆の影響と斷定する翋に行かない。又水田 化された谷に臨む臺地は地下水面が深くても古くから聚落が出來た例が少く ないので本村が地下水堆の爲に地下水面が淺くて出來たと推論出來ない。 
聚落發生の新舊は暫く措き蒙屋の粗密も德川時代は知らず明治42年測圖の 中野圖幅 (第10圖)からは認的られない。地下水堆の中央に街村があるが，靑 梅街道に沿つて出來たのであると云ふ方が至當であらう。

井荻, 天沼地下水堆は聚落の發生や發達に影響があつたものとは思はれる。 このことを積極的に主張するに足りる資料も今の所著者は有つてるない。現 在本地域に住宅が多いのは中央線に近く通勤に便利であることや中島飛行機 製作所があることの方がより直接であらう。しかし地下水面の踐いことは居 任性と云ふやうな都市衞生の方面から8全然人類社會に無關係であると云ふ ことも出來ないであらう。

確かに直接に影響があると思はれるのは近郊都市となる前に於ける水田の 分布である。妙正寺川や善福寺川の谷に沿ふ水田は別に珍しくないが阿佐っ 谷川上流の谷底は臺地面から $2 \mathrm{~m}$ 位しか低くないので，普通ならばよし玉川 上水の分水をかけて子第10圖に見られるやるには水田化し得られなかつたで あらう。地下水面の淺いことは水田存在の自然的條件の一として重要悓さる べきである。水田と地下水堆との關係は上宿地下水堆に就いても既に述べた 通りである(吉村1940)。

\section{摘 要}

1. 東京市杉並區の西，妙正寺川，善福寺川上流間の臺地に淺井帶があり， 地下水面が扁平ではあるが榢狀に盛上つてねて，地下水堆と考へられる。

2. 地下水堆は長さ $3.5 \mathrm{~km}$, 偪 $1.1 \mathrm{~km}$ に達し, 武藏野臺地に於ては最大で ある。地下水の動水傾斜は所々稍、大きくなつてわるが，地下水瀑布線附近 の地下水面のそれに比し著しく小さい。

3. 地下水堆は地形から云つて地下水の流出が少い上に厚くローム層下部に 粘土穈が存在するから生じたるのである。 
4. 聚落發生との間には閵係があるらしいが，現在の所證するに足る資料は 得られてるない。

\section{參考 交解}

清 野 信 雄 1935 : 東京地質圖幅說明書

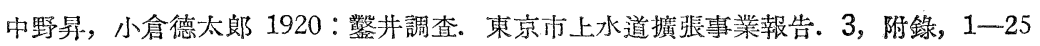

西尾銈次郎 1937 : 東京地方に於けるローム層の生成に就て。地質學雜誌，44，579一 581.

小田內通敏 1917 ：帝都の近郊

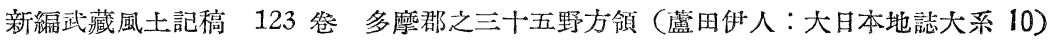

Stiny, J. 1936 : Zur Kenntnis der Formenentwicklung von Ouellenaustritten.

Zeit. Ges. Erdk. Berlin, 1936, 26-42.

鈴 木 敏 1888 : 東京地質圖幅說明書

高橋源一郎 1929 : 武藏野歷史地理, 2.

吉田東伍 1907 : 大日本地名箬書, 再版

吉村信 吉 1939 : 東京市西郊仙川池附近の地下水々聚落. 地理，2，525-527.

吉村 信吉 1940 : 東京本西郊保谷村上宿附近の地下水堆々聚落，淺い萑地，地理，3， 82-95.

吉村 信 吉 1940 ：東部武藏野臺地に於る地下水堆. 科學，10，9-10.

吉村 信 吉 1940 : 所濢町東方武藏野臺地地下水, 特に宙水之淺い滗地の成因, 聚落立 地々の關係，地理學渌論，16，145-169.

吉村 信 吉 1940 : 武藏野㗌地の地下水特に宙水, 地下水瀑布線, 地下水堆と聚落發達 との關係. 地理敎育, 32, 20-32. 